DOI https://doi.org/10.30525/978-9934-588-91-4-23

\title{
ЕПІЗОД 3 ІСТОРІЇ ВСТАНОВЛЕННЯ ВЛАДИ ДИРЕКТОРІЇ УНР У М. ЄЛИСАВЕТГРАДІ У ЛИСТОПАДІ-ГРУДНІ 1918 Р.
}

\author{
Тимошенко В. Л. \\ аспірант кафедри всесвітньої історії \\ Центральноукраӥнського державного педагогічного університету \\ імені Володимира Винниченка \\ м. Кропивницький, Украӥна
}

У листопаді - грудні 1918 р. в Слисаветграді склалася непроста соціально-економічна і політична ситуація. Місто та його мешканці були виснажені наслідками Першої світової війни та подіями початкового етапу Української революції. Українська держава гетьмана П. П. Скоропадського трималася значною мірою на німецьких багнетах, селянство було невдоволене продовольчими реквізиціями, природною реакцією на які стали масові антигетьманські повстання. Так, одне 3 перших великих селянських заворушень в Україні відбулося вже у травні 1918 року в околицях Слисаветграда. Тоді проти чинної влади піднялося понад 1000 селян [4, с. 128]. Паралельно з цим у межах краю розгорнуло роботу більшовицьке підпілля, організувалися загони отаманів Н. Григор'єва та А. Гулого-Гуленка, які оперували в Єлисаветградському повіті [3, с. 110-111]. Місто, на відміну від сіл краю, тривалий час зберігало толерантний нейтралітет стосовно центральної влади та ії дій.

Все різко змінилося в листопаді 1918 року, після підписання Комп'єнського перемир'я, за умовами якого поразкою для Німеччини та iii союзників закінчилася Перша світова війна. Ще у жовтні 1918 року П. П. Скоропадський, розуміючи, що Німеччина стоїть на порозі неминучого фіаско, намагався заручитися підтримкою Антанти, що обумовлювало зближення гетьмана 3 лідерами Білого руху та формування проросійського кабінету міністрів на чолі з С. М. Гербелем. Усе це в комплексі значно підірвало авторитет гетьманської влади. У листопаді 1918 р. в Україні розгорнулося антигетьманське повстання, у наслідок якого П. П. Скоропадський 14 грудня підписав маніфест про зречення та емігрував до Німеччини. Влада в країні перейшла до Директорії, яка відновила УНР.

У цих непростих умовах німецькі окупаційні війська почали поступову евакуацію. За спогадами німецького офіцера Г. Франца, вони виходили $з$ країни, охопленої «восстанием, в которой больше не существовало ни авторитета, ни порядка, где ияарили произвол и партизанская война...» [2, с. 183]. 
У Слисаветграді гетьманську владу було повалено в листопаді 1918 р. Це сталося за активної участі колишніх вільних козаків та за підтримки Українських Січових Стрільців [3, с. 103]. Під час відходу німецьких військ на залізничній станції Єлисаветград сталася збройна сутичка, оскільки німці, всупереч наказу Директорії УНР, намагалися дістатися залізницею до Знам'янки. На той час у місті дислокувалися 1-й та 2-й Січові полки, Кінний дивізіон отамана Д. Вербицького, Галицький курінь. У ході двогодинного бою німці відступили, в полон потрапило 300 німецьких солдатів, українські військові втратили 10 осіб [3, с. 108], які з почестями були поховані в Слисаветграді. Про це писала місцева газета «Друг народа», повідомляючи про «похорон козаків, убитих в бою 3 німцями 17 грудня 1918 року» [1, с. 198].

Про події грудня 1918 року на вокзалі в Єлисаветграді повідомляє німецький військовий журналіст, керівник прес-служби німецьких окупаційних військ у Миколаєві Вальтер Фест, який ще 1919 року опублікував спогади про події в Україні у 1918 році [5]. За його даними суть конфлікту в Єлисаветграді виглядає так: частини 9-го Ландштурмого полку намагалися виїхати 3 Слисаветграда до Знам'янки, користуючись договором про збереження нейтралітету, а українська сторона заявила, що не може пропустити частини полку до Знам'янки аби вони не об'єдналися 3 іншими німецькими частинами. При цьому німцям було рекомендовано прямувати в сторону «Бирсула-Казатин» [5, с. 121]. Німці на це не погодилися, оскільки на півдні їні частини «разоружали и грабили» [5, с. 121]. Не узгодивши дії, обидві сторони вступили в бій, в наслідок якого переважаючі українські частини завдали поразки німцям. За даними В. Феста в бою загинуло 47 осіб, 60 - отримали поранення. Серед останніх пізніше троє померли від ран та один від тифу. Також мемуарист повідомляє, що захоплені в полон німецькі солдати були пограбовані та жорстоко побиті. Поранені були переведені в лікарню Святої Анни [5, с. 122].

Провівши пошук інших документальних свідчень про описані вище події, нам вдалося встановити поіменний список німецьких солдат, які загинули в бою на вокзалі Єлисаветграда, який ми представляємо у таблиці 1.

Як бачимо, наведені дані підтверджують мемуари Вальтера Феста. Буремне XX століття на жаль не зберегло Лютеранське кладовище, воно було ліквідоване в радянський час, його територія нині забудована міськими промисловими об'єктами. Але повернення імен офіцерів і солдатів, навіть тих, які діяли по іншу сторону барикад, відіграє важливу роль для примирення народів та повернення історичної пам'яті. 
Таблиця 1

Солдати 9-го Ландштурмного полку, які загинули в бою на вокзалі в Слисветграді у грудні 1918 року за даними метричних записів церкви Святої Марії м. Слисаветграда Херсонської губернії

[6, арк. 144-149]

\begin{tabular}{|c|c|c|c|c|}
\hline $\begin{array}{c}\text { Дата } \\
\text { смерті } \\
\text { (ст./нов. } \\
\text { стиль) }\end{array}$ & $\begin{array}{c}\text { Дата } \\
\text { похо- } \\
\text { вання } \\
\text { (ст./нов. } \\
\text { стиль) }\end{array}$ & $\begin{array}{c}\text { Прізвище та } \\
\text { ім'я }\end{array}$ & $\begin{array}{l}\text { Звання, військовий } \\
\text { підрозділ, вік }\end{array}$ & $\begin{array}{c}\text { Місце } \\
\text { поховання }\end{array}$ \\
\hline 1 & 2 & 3 & 4 & 5 \\
\hline $\begin{array}{l}05 / 18.12 . \\
1918\end{array}$ & $\begin{array}{l}09 / 22.12 . \\
1918\end{array}$ & Елерс Клаус & \multirow{14}{*}{ 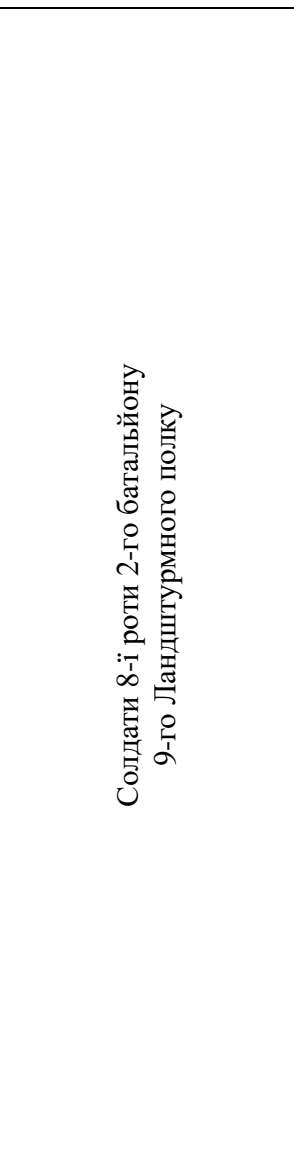 } & \multirow{14}{*}{ 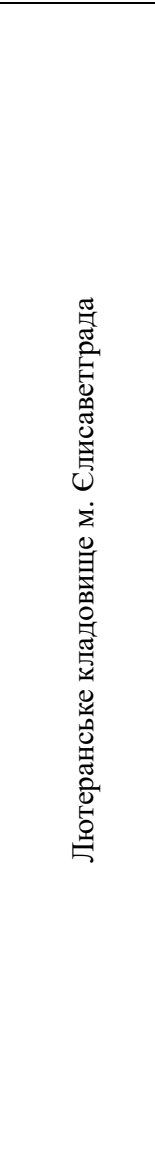 } \\
\hline $\begin{array}{l}05 / 18.12 \\
1918\end{array}$ & $\begin{array}{l}09 / 22.12 . \\
1918\end{array}$ & $\begin{array}{l}\text { Брандіс } \\
\text { Вільгельм }\end{array}$ & & \\
\hline $\begin{array}{l}05 / 18.12 . \\
1918\end{array}$ & $\begin{array}{l}09 / 22.12 . \\
1918\end{array}$ & Зель Юрген & & \\
\hline $\begin{array}{l}05 / 18.12 \\
1918\end{array}$ & $\begin{array}{l}09 / 22.12 \\
1918\end{array}$ & $\begin{array}{l}\text { Брейгольц } \\
\text { Йоганес }\end{array}$ & & \\
\hline $\begin{array}{l}05 / 18.12 \\
1918\end{array}$ & $\begin{array}{l}09 / 22.12 \\
1918\end{array}$ & $\begin{array}{l}\text { Фіман } \\
\text { Вільгельм }\end{array}$ & & \\
\hline $\begin{array}{l}05 / 18.12 \\
1918\end{array}$ & $\begin{array}{l}09 / 22.12 . \\
1918\end{array}$ & $\begin{array}{l}\text { Гольтгоф } \\
\text { Гейндріх }\end{array}$ & & \\
\hline $\begin{array}{l}05 / 18.12 \\
1918\end{array}$ & $\begin{array}{l}09 / 22.12 . \\
1918\end{array}$ & $\begin{array}{l}\text { Роведер } \\
\text { Генріх }\end{array}$ & & \\
\hline $\begin{array}{l}05 / 18.12 \\
1918\end{array}$ & $\begin{array}{l}09 / 22.12 \\
1918\end{array}$ & $\begin{array}{l}\text { Беренгрубе } \\
\text { Вільгельм }\end{array}$ & & \\
\hline $\begin{array}{l}05 / 18.12 \\
1918\end{array}$ & $\begin{array}{l}09 / 22.12 . \\
1918\end{array}$ & Матіс Гуго & & \\
\hline $\begin{array}{l}05 / 18.12 \\
1918\end{array}$ & $\begin{array}{l}09 / 22.12 \\
1918\end{array}$ & $\begin{array}{l}\text { Енгелькен } \\
\text { Гейнріх }\end{array}$ & & \\
\hline $\begin{array}{l}05 / 18.12 . \\
1918\end{array}$ & $\begin{array}{l}09 / 22.12 . \\
1918\end{array}$ & Залінг Генріх & & \\
\hline $\begin{array}{l}05 / 18.12 \\
1918\end{array}$ & $\begin{array}{l}09 / 22.12 . \\
1918\end{array}$ & $\begin{array}{l}\text { Еверс } \\
\text { Гейнріх }\end{array}$ & & \\
\hline $\begin{array}{l}05 / 18.12 . \\
1918\end{array}$ & $\begin{array}{l}09 / 22.12 . \\
1918\end{array}$ & Функ Ганс & & \\
\hline $\begin{array}{l}05 / 18.12 . \\
1918\end{array}$ & $\begin{array}{l}09 / 22.12 . \\
1918\end{array}$ & Шмілау Карл & & \\
\hline
\end{tabular}


Продовження таблиці 1

\begin{tabular}{|c|c|c|c|c|}
\hline 1 & 2 & 3 & 4 & 5 \\
\hline $\begin{array}{l}05 / 18.12 \\
1918\end{array}$ & $\begin{array}{l}09 / 22.12 \\
1918\end{array}$ & Дозе Іоанн & \multirow{2}{*}{$\begin{array}{l}\text { Солдати } \\
7 \text {-ї роти } \\
\text { 2-го батальйону } \\
\text { 9-го Ландштурмного } \\
\text { полку }\end{array}$} & \multirow{2}{*}{ 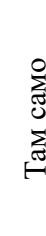 } \\
\hline $\begin{array}{l}05 / 18.12 \\
1918\end{array}$ & $\begin{array}{l}09 / 22.12 \\
1918\end{array}$ & Гольц Густав & & \\
\hline $\begin{array}{l}05 / 18.12 \\
1918\end{array}$ & $\begin{array}{l}09 / 22.12 \\
1918\end{array}$ & Теннес Іоанн & \multirow{3}{*}{$\begin{array}{l}\text { Солдати } \\
\text { 7-ї роти } \\
\text { 2-го батальйону } \\
\text { 9-го Ландштурмного } \\
\text { полку }\end{array}$} & \multirow{3}{*}{ 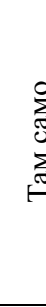 } \\
\hline $\begin{array}{l}05 / 18.12 \\
1918\end{array}$ & $\begin{array}{l}09 / 22.12 \\
1918\end{array}$ & $\begin{array}{l}\text { Людерс } \\
\text { Густав }\end{array}$ & & \\
\hline $\begin{array}{l}05 / 18.12 \\
1918\end{array}$ & $\begin{array}{l}09 / 22.12 . \\
1918\end{array}$ & Горн Макс & & \\
\hline $\begin{array}{l}05 / 18.12 \\
1918\end{array}$ & $\begin{array}{l}09 / 22.12 . \\
1918\end{array}$ & $\begin{array}{l}\text { Борстель } \\
\text { Фріц }\end{array}$ & \multirow{3}{*}{$\begin{array}{l}\text { Солдати кулеметної } \\
\text { роти (M.G.1.II) }\end{array}$} & \multirow{3}{*}{ 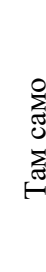 } \\
\hline $\begin{array}{l}05 / 18.12 \\
1918\end{array}$ & $\begin{array}{l}09 / 22.12 \\
1918\end{array}$ & $\begin{array}{l}\text { Горн } \\
\text { Христіан }\end{array}$ & & \\
\hline $\begin{array}{l}05 / 18.12 \\
1918\end{array}$ & $\begin{array}{l}09 / 22.12 \\
1918\end{array}$ & $\begin{array}{l}\text { Рейтер } \\
\text { Гейнріх }\end{array}$ & & \\
\hline $\begin{array}{l}05 / 18.12 \\
1918\end{array}$ & $\begin{array}{l}09 / 22.12 . \\
1918\end{array}$ & Губер Карл & \multirow{2}{*}{ 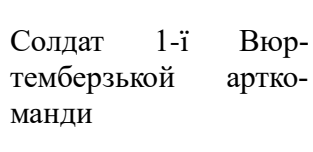 } & \multirow{2}{*}{ 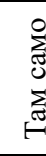 } \\
\hline $\begin{array}{l}05 / 18.12 \\
1918\end{array}$ & $\begin{array}{l}09 / 22.12 . \\
1918\end{array}$ & $\begin{array}{l}\text { Бек (ім'я } \\
\text { невідоме) }\end{array}$ & & \\
\hline $\begin{array}{l}05 / 18.12 . \\
1918\end{array}$ & $\begin{array}{l}09 / 22.12 . \\
1918\end{array}$ & Голерц Отто & \multirow{2}{*}{$\begin{array}{l}\text { Солдати 7-ї роти } \\
\text { 2-го батальйону } \\
9 \text {-го Ландштурмного } \\
\text { полку }\end{array}$} & \multirow{2}{*}{ 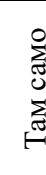 } \\
\hline $\begin{array}{l}05 / 18.12 \\
1918\end{array}$ & $\begin{array}{l}09 / 22.12 \\
1918\end{array}$ & $\begin{array}{l}\text { Козловский } \\
\text { Самуіл }\end{array}$ & & \\
\hline $\begin{array}{l}05 / 18.12 \\
1918\end{array}$ & $\begin{array}{l}09 / 22.12 . \\
1918\end{array}$ & $\begin{array}{l}\text { Шнейдер } \\
\text { Альфонс }\end{array}$ & \multirow{2}{*}{$\begin{array}{lr}\text { Солдат } \quad 1-і ̈ & \text { Вюр- } \\
\text { темберзькой } & \text { артк-- } \\
\text { манди } & \end{array}$} & \multirow{2}{*}{ 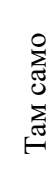 } \\
\hline $\begin{array}{l}05 / 18.12 \\
1918\end{array}$ & $\begin{array}{l}09 / 22.12 \\
1918\end{array}$ & $\begin{array}{l}\text { Йогансен } \\
\text { Йос }\end{array}$ & & \\
\hline $\begin{array}{l}05 / 18.12 \\
1918\end{array}$ & $\begin{array}{l}09 / 22.12 \\
1918\end{array}$ & $\begin{array}{l}\text { Вагнер } \\
\text { Ріхард }\end{array}$ & $\begin{array}{l}\text { Солдат 6-ї роти } \\
\text { 2-го батальйону } \\
\text { 9-го Ландштурмного } \\
\text { полку }\end{array}$ & 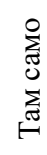 \\
\hline
\end{tabular}


Продовження таблиці 1

\begin{tabular}{|c|c|c|c|c|}
\hline 1 & 2 & 3 & 4 & 5 \\
\hline $\begin{array}{l}05 / 18.12 \\
1918\end{array}$ & $\begin{array}{l}09 / 22.12 \\
1918\end{array}$ & $\begin{array}{l}\text { Гейнц } \\
\text { Адольф }\end{array}$ & $\begin{array}{l}\text { Солдат 7-ї роти } \\
\text { 2-го батальйону } \\
\text { 9-го Ландштурмного } \\
\text { полку }\end{array}$ & 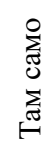 \\
\hline $\begin{array}{l}05 / 18.12 \\
1918\end{array}$ & $\begin{array}{l}09 / 22.12 \\
1918\end{array}$ & $\begin{array}{l}\text { Дюренбах } \\
\text { Маттеас }\end{array}$ & $\begin{array}{l}\text { Солдат } \quad \text { кулеметної } \\
\text { команди (M.G.C.) }\end{array}$ & 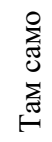 \\
\hline $\begin{array}{l}05 / 18.12 \\
1918\end{array}$ & $\begin{array}{l}09 / 22.12 \\
1918\end{array}$ & $\begin{array}{l}16 \text { невідомих. } \\
\text { Між ними } \\
\text { лейтенант } \\
\text { Вольф Гросс? }\end{array}$ & - & $\stackrel{\circ}{\beth}$ \\
\hline $\begin{array}{l}05 / 18.12 \\
1918\end{array}$ & $\begin{array}{l}09 / 22.12 \\
1918\end{array}$ & $\begin{array}{l}\text { 3-поміж } \\
\text { невпізнаних } \\
\text { Буш Гейнріх, } \\
\text { Фрідріх } \\
\text { Дітріх }\end{array}$ & - & 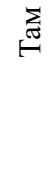 \\
\hline $\begin{array}{l}06 / 19.12 \\
1918\end{array}$ & - & $\begin{array}{l}\text { Гельміке } \\
\text { (ім'я } \\
\text { записане не } \\
\text { розбірливо) }\end{array}$ & $\begin{array}{l}\text { Солдат 7-ї роти } \\
\text { 2-го батальйону } \\
\text { 9-го Ландштурмного } \\
\text { полку }\end{array}$ & 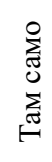 \\
\hline $\begin{array}{l}31.12 \\
1918\end{array}$ & $\begin{array}{l}03.01 \\
1919\end{array}$ & $\begin{array}{l}\text { Німейер } \\
\text { Герман }\end{array}$ & $\begin{array}{l}\text { Солдат 6-ї роти } \\
\text { 2-го батальйону } \\
\text { 9-го Ландштурмного } \\
\text { полку, } 44 \text { года }\end{array}$ & 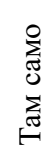 \\
\hline $\begin{array}{l}02.01 \\
1919\end{array}$ & $\begin{array}{l}03.01 \\
1919\end{array}$ & $\begin{array}{l}\text { Мейер } \\
\text { Йоганн }\end{array}$ & $\begin{array}{l}\text { Солдат 8-ї роти } \\
\text { 2-го батальйону } \\
\text { 9-го Ландштурмного } \\
\text { полку, } 44 \text { года }\end{array}$ & 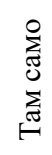 \\
\hline
\end{tabular}


Продовження таблиці 1

\begin{tabular}{|c|c|c|c|c|}
\hline 1 & 2 & 3 & 4 & 5 \\
\hline $\begin{array}{l}02.02 . \\
1919\end{array}$ & $\begin{array}{l}10.02 . \\
1919\end{array}$ & Бауер Ріхард & $\begin{array}{l}\text { Солдат 6-ї роти } \\
\text { 2-го батальйону } \\
\text { 9-го Ландштурмного } \\
\text { полку, } 44 \text { года }\end{array}$ & 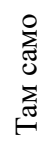 \\
\hline $\begin{array}{l}18.02 . \\
1919\end{array}$ & $\begin{array}{l}19.02 . \\
1919\end{array}$ & $\begin{array}{l}\text { Рейман } \\
\text { Фрідріх }\end{array}$ & $\begin{array}{l}\text { Солдат 8-ї роти } \\
\text { 2-го батальйону } \\
\text { 9-го Ландштурмного } \\
\text { полку, } 43 \text { года }\end{array}$ & 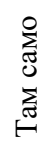 \\
\hline
\end{tabular}

\section{Лiтература:}

1. Вівсяна I. А. Соборницька місія Українських Січових Стрільців у Наддніпрянщині. Науково-популярне видання - Харків, 2018. - 372 с.

2. Петров В. И. Непокорившиеся кайзеровскому нашествию/ Отв. ред. В.П.Наумов. - М.: Наука, 1988. - 208 с.

3. Роки боротьби 1917-1922pp. на Слисаветчині. Український погляд. 1917-1918pp. Початок революційної стихії. Книга перша / Авт.упоряд.Ю.С.Митрофаненко. - Кропивницький: Імекс-ЛТД, 2018. $212 \mathrm{c}$.

4. Савченко В. В. Двенадцать войн за Украину / Худож.оформитель А.А.Ленчик. - Харьков: Фолио, 2006. - 415 с.

5. Фест В. Николаев - последний форпост немецких войск на Черном море. - Николаев: Юрий Любаров, Анатолий Пацюк, 2016. $192 \mathrm{c}$.

6. Церковная книга умерших прихода Церкви Св.Марии. Томь XXIII. г. Елисаветграда (1892-1921). - Державний архів Кіровоградської області. - Ф. 834. - Оп. 1. - Од. зб. 7. - 168 арк. 